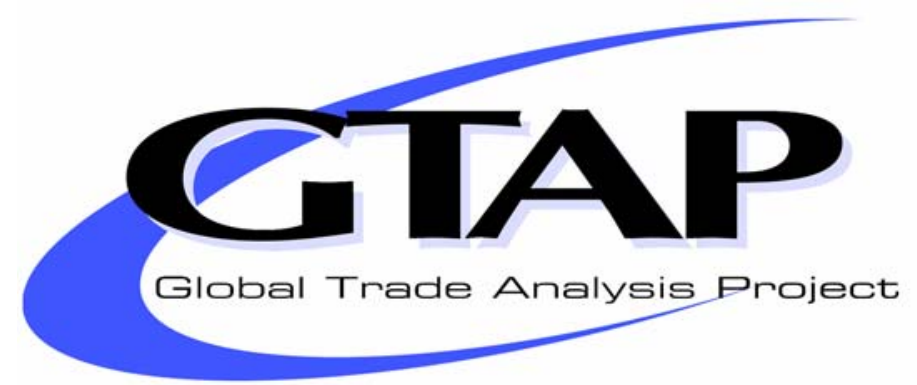

\title{
Bilateral Free Trade Agreements and Customs Unions: The Impact of the EU Republic of South Africa Free Trade Agreement on Botswana1
}

\author{
Scott McDonald \\ and \\ Terrie L. Walmsley
}

GTAP Working Paper No. 29

2003

Previous versions of this paper were presented at the Development Economics Study Group's Annual Conference, University of Nottingham, April 2001, the Global Economic Analysis Conference, Purdue University, June 2001 and the Agricultural Economics Association of South Africa's Annual Conference, Champagne Castle, Drakensberg, September 2001. The authors are grateful for helpful comments by participants at those conferences, but are responsible for any remaining errors. 


\title{
Bilateral Free Trade Agreements and Customs Unions: The Impact of the EU Republic of South Africa Free Trade Agreement on Botswana
}

\begin{abstract}
The EU has indicated that after 2008 its trade relationships with developing countries will be dominated by the development of preferential trade agreements. Although not a consequence of the Cotonou Agreement, the free trade agreement between the EU and the Republic of South Africa (EU RSA FTA) is clearly one of the first fruits of this approach to trade relationships. However, there is no evidence that the design of the EU RSA FTA incorporated a comprehensive general equilibrium evaluation of the agreement for either the signatories or the other southern African nations. The analyses reported here indicate that while the EU RSA FTA may substantially benefit the signatories, there are appreciable negative impacts for other states, especially the RSA's immediate neighbours. Moreover, the reluctance of the EU to fully liberalise trade in food and agriculture commodities results in a major reduction in the benefits for the RSA without ameliorating substantively the adverse implications for other nations.
\end{abstract}

Keywords:

JEL classification: 


\section{Introduction}

The Southern Africa Customs Union (SACU) has five members, the Republic of South Africa (RSA), ${ }^{2}$ and Botswana, Lesotho, Namibia and Swaziland, ${ }^{3}$ the so-called BLNS countries, and is the world's longest standing customs union (established in 1910). For most of SACU's existence the BLNS countries were colonies. A legacy of those political arrangements was that SACU's trade relations were determined, almost unilaterally, by the RSA: a situation that is now a subject of negotiations. Since the late 1980s SACU's trade barriers have been severely reduced, and hence the tariff revenues received by the member states under SACU's tariff revenue sharing formula have also declined. The BLNS governments were historically dependent on tariff revenue, and although the importance of tariff revenues has declined for Botswana and Swaziland, the governments of Lesotho and Namibia have more limited alternative revenue raising capacities. Recently the government of the RSA has entered into a (unilateral) free trade agreement with the EU (EU RSA FTA), and is further considering the possibility of a (unilateral) free trade agreement with MERCUSOR. ${ }^{4}$ The BLNS countries have expressed concern about the implications of the EU RSA FTA for their economies, and to date have not endorsed the arrangements.

An important feature of the EU RSA FTA is the implicit asymmetry of trade liberalisation between the EU and the BLNS countries. Because of the SACU, the EU RSA FTA effectively grants the EU free access to the markets of the BLNS countries but does not grant the BLNS countries reciprocal access to the EU's markets. ${ }^{5}$ With the proliferation of preferential trade agreements (PTA) since the forming of the World Trade Organisation (WTO) it is likely that more and more PTAs will be formed between states that are signatories to other agreements, and where the preferences provided by a new agreement do not extend to other countries in existing agreements. How these multiple agreements interact is likely to become an important consideration in both the framing of PTAs and in efforts to ensure that PTAs do not have adverse unintended effects. In particular it may be deemed important to ensure that the least developed nations, who are small, vulnerable and disproportionately concentrated in Africa, are not adversely affected.

This paper reports the results from a comparative static variant of the GTAP model that quantifies the impact on Botswana of the EU RSA FTA. Hence, by definition, the analyses are concerned with the impact of an FTA upon a small country. The model is calibrated using data from GTAP 5. The southern Africa disaggregation in GTAP 5 separately identifies Botswana from the rest of SACU, and hence for the first time renders possible analyses of intra-SACU relationships, albeit partial analyses. A novel feature of the analyses is the modeling of the

2 Throughout this paper the abbreviation RSA will be used to refer to the political entity of the Republic of South Africa. The term South Africa will be reserved for use defining the region identified in the GTAP Data Base that includes the RSA, along with Lesotho, Swaziland and Namibia.

3 Throughout this paper countries will be referred to by their current names rather than the names in use at those points in time being discussed.

4 Strictly speaking the term free trade agreement is inappropriate. The EU RSA FTA does not include the complete liberalisation of trade between the EU and the RSA, and hence the agreement would be better described as a preferential trade agreement if the terms are to be consistent with the literature. However, the EU and RSA have adopted the term FTA.

This assumes that rules of origin are effective. The complications raised by rules of origin are sidestepped in the analyses reported below and therefore are not discussed in this paper. This of course does not render them irrelevant. 
revenue sharing arrangements of SACU. The tariff revenues for SACU are pooled and then divided between the two regions on the basis of a revenue sharing formula. The paper will report model simulations that assess both the impact of the EU RSA FTA on Botswana, South Africa and other regions, where South Africa is defined as the SACU states other than Botswana.

The rest of this paper is organized as follows. The next section briefly reviews the history and current state of the SACU. Section 3 surveys the basic arrangements proposed by the EU RSA FTA. The data and model used for the analyses are described in the two sub-sections of section 4, with descriptions of the policy experiments and comments on the results appearing in section 5. Concluding comments appear in section 6 .

\section{Southern African Customs Union}

The SACU was formed in 1910 between the RSA and Botswana, Lesotho and Swaziland (BLS). The origins of the SACU therefore coincide with the establishment of the RSA and during a period in history when the BLS states were colonies/protectorates of the UK. Moreover, the SACU was a union between states that were very unequal (Table 1 provides some structural information about the SACU members for more recent years) and different in terms of size and economic wealth and geographic location. From the late $19^{\text {th }}$ century the mineral wealth of the RSA was well known and the object of large investments and rapid expansions, which contributed to rapidly rising incomes for the Caucasian minority. ${ }^{6}$ There was a buoyant demand for labour throughout the RSA, which stimulated the development of migrant labour schemes to support the mines and cities of the RSA. The migrant labour schemes operated throughout southern Africa, but were particularly important for the BLS economies and encouraged the development of a partially integrated labour market in the SACU, but the inter country flows of labour have never been free. The lack of comparable development in the BLS countries resulted in remittances from migrant labour to the BLS countries being important components of national income (see for instance Lucas and Stark, 1985a and b, and Stark and Lucas, 1988). The economic dominance of the RSA was compounded by the geographic dependence of the BLS countries. Lesotho is completely surrounded by South Africa, while Botswana's key trade routes pass through South Africa. ${ }^{7}$ Swaziland does possess greater alternatives because of its proximity to Maputo.

6 Although average incomes for Caucasians rose rapidly their distribution was heavily skewed, as was the distribution of economic power.

7 Botswana has access by rail to the sea through Zimbabwe (on 'Rhodes's' railway) and since 1999 by road across the Kalahari to Walvis Bay in Namibia. 
Table 1 Structural Characteristics of the SACU Member States

\begin{tabular}{|c|c|c|c|c|c|c|}
\hline & RSA & Botswana & Lesotho & & Namibia & Swaziland \\
\hline Area (sq km) & $1,221,040$ & 566,730 & 30,350 & & 823,290 & 17,200 \\
\hline \multicolumn{7}{|l|}{1965} \\
\hline GNP per capita ( $\$$ curr) & 520 & 80 & 60 &.. & & 180 \\
\hline Population ('000) & 19,832 & 549 & 963 & & 713 & 370 \\
\hline GDP (\$USm curr) & 10,755 & 46 & 55 &.. & & 78 \\
\hline \multicolumn{7}{|l|}{ Shares of GDP } \\
\hline Agriculture & 10.14 & 36.04 & 65.24 &.. & & 34.66 \\
\hline Industry & 41.39 & 20.45 & 4.81 &.. & & 32.99 \\
\hline Manufacturing & 23.92 & 12.34 & 0.80 &.. & & 8.56 \\
\hline Services & 48.48 & 50.00 & 29.95 & .. & & 32.36 \\
\hline \multicolumn{7}{|l|}{1999} \\
\hline GNP per capita ( $\$$ curr) & 3,160 & 3,020 & 770 & & 2,000 & 1,170 \\
\hline Population ('000) & 41,457 & 1,450 & 1,980 & & 1,545 & 900 \\
\hline GDP (\$USm curr) & 130,220 & 5,053 & 957 & & 3,475 & 1,326 \\
\hline \multicolumn{7}{|l|}{ Shares of GDP } \\
\hline Agriculture & 4.68 & 5.09 & 10.09 &.. & & 9.03 \\
\hline Industry & 31.44 & 46.44 & 55.51 &.. & & 85.62 \\
\hline Manufacturing & 24.06 & 3.97 & 18.10 &.. & & 36.30 \\
\hline Services & 63.88 & 48.48 & 34.40 &.. & & 5.35 \\
\hline
\end{tabular}

Source: World Development Indicators

Over and above these factors lies the matter of political status. As colonies with few known resources and apparently little economic worth to the UK, the BLS countries had little or no say over the direction of the SACU. A situation that also applied to Namibia, who became a de facto member of the SACU when the RSA took political control under a League of Nations mandate. Consequently it is not surprising that the arrangements of the SACU were dominated by the RSA until the BLS countries gained independence.

The SACU provides for a common external tariff and complete free trade in commodities between the member states, whilst granting transit rights across the RSA for the other members. Tariff revenues are collected by the RSA and then distributed among the members according to a revenue sharing formula. The degree of integration is assisted by the use of a common currency, except in Botswana where the exchange rate is managed such that, to a substantial degree, the Pula tracks the Rand. 
While the SACU remains an agreement between unequal states, there has been a substantial change since the late 1960s. The BLS countries gained independent political status in the 1960s, and this was undoubtedly a major factor behind the renegotiation of the SACU agreement in 1969, which produced a revised agreement that came into being on $1^{\text {st }}$ March 1970 . Similarly, when Namibia gained independence from the RSA, in 1990, it became an independent political entity in the SACU. The ending of the apartheid regime in the RSA has heralded the start of a further renegotiation of the SACU agreement. While there is evidence that the revised institutional arrangements have been agreed and that a new revenue sharing formula has been provisionally agreed, other matters (see below) are blocking a final agreement (MFDP, 2001).

Table 1 indicates the degree to which the relative economic performances of the SACU members have changed over time. The RSA remains the dominant economic force, but this is increasingly a consequence of the size of its population and the relative strength of its industrial base rather than crude income per capita. Historially the RSA enjoyed carte blanche over the setting of tariff and excise duty rates for SACU, and used implicit threats, not least over transit rights, to reinforce its control. Consequently the development of trade policies within the SACU was determined by the 'development' agenda of the RSA.

The post second world war era saw the RSA adopt increasingly inward looking development strategies. These policies emphasised import substituting industrialization (ISI), the development of 'strategic' industries and downstream processing of mineral products. But, unlike many other countries pursuing ISI style policies, agriculture was heavily supported. ${ }^{8}$ What is not clear is the extent to which the core economic policy vision was some form of ISI strategy as opposed to being driven by the political ideology of apartheid and subsequent responses to international opprobrium. Nevertheless it is clear that by the late 1980s the RSA, and hence SACU, had acquired a bewildering array of trade policy instruments; quantitative restrictions, multiple tariff lines, a multiplicity of forms of protection, all overridden by exemptions (see Holden, 1992, for a review). For agriculture these instruments were compounded by price controls, marketing boards, ordinances, statutes and regulations (see Vink and Kassier, 1992). The degree to which these trade policies were responsible for the two decades of stagnation and decline, and the three and half-year recession that the RSA experienced before the change of government in April 1994 will probably never be fully known. It is difficult to believe that the trade policies made no contribution, but equally it is hard to argue a case that ignores the other policies of the apartheid era, especially those policies that contributed to the chronic shortage of skilled labour and how international ostracisation contributed to the confusing plethora of duty rates and instruments.

What cannot be disputed is that the BLNS countries were at least partly compelled, through membership of the SACU, to follow the trade policies of the RSA. Even before the change of government the protectionist policies had become unsustainable and the RSA embarked on a regime of progressive reform. Agricultural support policies were substantially dismantled, which given the dependence of the BLNS countries on food imports should have produced positive welfare effects. ${ }^{9}$ Similarly other tariffs were reduced, but the SACU tariff structure remains complex (see Lewis, 2001).

8 The political influence of farmers (Boers) probably increased when the National Party came to power, but the protection of agriculture long predates that event, e.g., the 1913 Land Act (see Binswanger and Deininger, 1993, and Deininger and Binswanger, 1995).

$9 \quad$ There was also a move away from self-sufficiency to food-security within Botswana during the late 1990s. 


\section{The EU Republic of South Africa Free Trade Agreement}

The trade relationships between southern and eastern African states are difficult to disentangle. A plethora of trade and economic cooperation agreements exist both between the states of the region and between states within the region and outside. The major multi lateral agreements are the SACU, the Southern African Development Community (SADC), the Common Market for Eastern and Southern Africa (COMESA), and the Cross-Border Initiative (CBI). How each is impacting upon the performance of any individual state is difficult to clearly articulate since the memberships of each agreement are not exclusive (see Lewis, 2001). Currently the most comprehensive organisation, in terms of membership, is COMESA but it appears to be somewhat fragile. In the longer term it may be that SADC emerges as the primary organisation among southern African states; one vision of the SADC agreement is a common market with free movements of commodities, capital, labour and services. However progress towards those objectives seems to be slow with the majority of agreements being partial, e.g., trade concessions to Malawi, Mozambique, Tanzania and Zambia by the SACU under the SADC Trade Protocol.

At the moment therefore the SACU remains the only trade agreement in southern Africa that is fully functioning. In this context the EU RSA FTA, and the ongoing talks between RSA and MERCUSOR and Brazil, 10 represent an interesting departure. In particular they raise the question of how long a customs union can continue to operate when one member engages in unilateral negotiations with third parties that will ultimately lead to changes in common tariff rates.

The EU RSA FTA originated in 1995 in response to a proposal by the EU. It would seem that the RSA was initially primarily interested in acquiring full Lomé Convention membership, but when the RSA only achieved partial membership the prospect of gaining greater access to the EU market through a FTA seems to have been regarded as an attractive alternative. In light of the Cotonou agreement and the EU's subsequent commitment to seek regional trade agreements (RTA) with ACP (African, Caribbean and Pacific) countries and other developing countries, whilst phasing out the preferential commodity agreements, the EU's proposals to the RSA would seem to fit a pattern that has subsequently emerged.

Agreement on the EU RSA FTA finally came in 1999. The agreement covers the vast majority of commodities, although there are a number of contentious issues remaining particularly with respect to the EU retaining protection for certain 'sensitive' agricultural products. To all intents and purposes the EU agreed to phase out all trade barriers with the RSA over 10 years while the RSA reciprocated over 12 years, with the exception of some 'sensitive' food and agricultural commodities. The programme of mutual liberalisation includes a banding of products according to the stage in the liberalisation process at which the trade barriers would be reduced; it has been suggested that the slow implementation of agricultural trade liberalisation, especially for products in which the RSA is expected to have export potential (vegetables, fruit, meat and some wines) mean that the RSA's gains might be limited. This argument is further supported by the more rapid liberalisation of trade in manufactured than agricultural commodities.

Despite the EU and the RSA reaching agreement on the FTA in 1999, it remains unratified by the BLNS countries. Beside the obvious political questions raised by the FTA, there are a number 
of important economic questions. Of particular concern to the BLNS countries is the question of how the EU RSA FTA will impact upon their economies. While several CGE studies using GTAP 4 data (Lewis et al., 1999; Penzhorn, 2000) have suggested that SACU as a whole would benefit, these studies have been constrained by the data base to not address the issue of the distribution of gains and losses within SACU. One study (IDS and BIDPA, 1998) suggested that the BLNS countries would experience relatively minor effects in terms of trade flows, on the basis of a commodity flow model. However it was noted that the revenue effects, principally for Lesotho and Namibia, might be appreciable, although Botswana would be relatively unaffected due to its low dependence on trade taxes.

It may be that the potential benefits of the EU RSA FTA depend upon the dynamic effects of the agreement. For instance, if the agreement fosters faster growth in the RSA then it could be argued that the BLNS countries would benefit by the trade creation effect of RSA growth. However, this presumes that the BLNS countries would capture an appreciable share of import expansion by the RSA, an outcome that may be doubtful given the currently low level of penetration of the RSA market by BLNS exports. In the meantime ratification of the EU RSA FTA by the BLNS countries must almost certainly await a final agreement on a support and compensation package for the BLNS countries. A key problem with such a package will be quantification, which is a process to which this study seeks to contribute.

\section{Data and Model}

The data and model used for the analyses reported here derive from the Global Trade Analysis Project (GTAP). The heart of the GTAP is its data base that contains a fully articulated record of trade transactions and duties between different regions for a range of commodities (see Gehlhar et al., 1997). The number of regions and commodities has increased steadily with each release of the data base, such that GTAP 5, the fifth release, has data for 66 regions and 57 commodities. Associated with the data base is the GTAP model (see Hertel and Tsigas, 1997). This is a computable general equilibrium (CGE) model that incorporates one particular specification of behavioural relationships that are consistent with the data; as with all CGE models, this represents one of many possible specifications. ${ }^{11}$ The GTAP model is typically solved in rates of change, although again this is a matter of preference rather than substance. ${ }^{12}$

\section{Data}

The trade transactions, recorded in the GTAP Data Base (Dimaranan and McDougall, 2002), distinguish between commodities on the basis of their regions of origin and destination, but also on the basis of the agents (intermediate demand, and final demand by household, government and investment ${ }^{13}$ ) that absorb the commodities in the importing economy. This provides a method for

11 Lewis et al., (1999 and 2001) report results from an alternative specification of CGE model using data from GTAP.

12 Lewis et al., (1999 and 2001) use a CGE model that is solved in terms of levels using the GAMS software. Rutherford (2000) has produced a specification of the GTAP model that is solved using the GAMS software. The GTAP model uses the GEMPACK software. 
allowing for the varying import intensities by different agents within a region. ${ }^{14}$ Trade tax data are recorded for each and every trade transaction.

The remaining data in the GTAP Data Base are region specific and serve primarily to support the trade data and the trade focus of its intended applications. Domestic absorption is accounted for by intermediate demand, and final demand by the household, government and investment. Domestic agents not only pay import duties, but commodity purchases are also subject to sales taxes. Domestic supply is provided by activities that each produce a single characteristic commodity, which is either sold on the domestic market or exported. In addition to purchasing intermediate inputs, the activities also purchase combinations of five primary factors - land, capital, natural resources and skilled and unskilled labour - and pay indirect/production taxes. The 'regional' household receives all income from factor sales. This income is then distributed to the private household, ${ }^{15}$ savings and government. There are five different tax instruments import and export duties, sales/commodity taxes, production taxes and factor taxes. ${ }^{16}$ The capital account draws together savings by the regional household and the rest of the world (external balance), and disburses those funds to investment by commodity (domestic and imported).

Table 2 Model Commodities and Regions

\begin{tabular}{ll}
\hline Model Commodities & Model Region \\
\hline Crop Agriculture & Botswana \\
Animal Agriculture & South Africa \\
Fuels \& Minerals & Rest of SADC \\
Food Products & Rest of Africa \\
Textiles & EU \\
Heavy Manufacturing & NAFTA \\
Light Manufacturing & MERCUSOR \\
Utilities & Rest of Europe \\
Construction & Rest of America \\
Services & Rest of the World \\
\hline
\end{tabular}

The model used for this study uses data from the GTAP 5 Data Base. Although the data bases allows for 57 commodities and 66 regions the analyses reported here uses a 10 commodity (2 agriculture, 1 extraction, 4 manufacturing, utilities, construction and services) by 10-region (4

All known CGE models use variants of the Armington assumption (Armington, 1969) and therefore the results of policy experiments are sensitive to both substitution elasticities and trade shares (see de Melo and Robinson, 1989).

15 The single household specification means that GTAP models can only provide limited information on the within country income distribution implications of policy changes.

16 The recorded factor tax rates are minimal. The data base does not include income taxes, even for regions where they represent a substantial component of government income; effectively they are subsumed within the distribution of the income of the regional households as fixed shares. 
Africa, 2 Europe, 3 Americas, and Rest of World) aggregation. The commodity and region groups used for this model's data base are listed in Table 2, while details of the aggregation mappings used are reported in Appendix 1. The commodity and regional aggregations reflect the known patterns of trade and the various trade agreements that have been entered into or are anticipated for the RSA and the SACU. A distinctive feature of the regional aggregation is the identification of Botswana as a separate entity from SACU; this allows the analyses to assess the intra-SACU implications of reform that Lewis et al., (1999) and Penzhorn (2000) could not address, and the identification of a region for the rest of SADC, which allows consideration of the impact of the agreement upon the RSA's southern African partners. Hereafter the regions Botswana, South Africa and rest of SADC will be referred to collectively as SADC. ${ }^{17}$

However, as of mid 2002, the GTAP 5 Data Base does not report common import tariff rates for Botswana and South Africa, despite them being members of a customs union. The differences in the tariff rates are sufficiently large as to indicate that this is not a consequence of the aggregation used in the data base. It is therefore necessary to adjust the data base so that common tariff rates exist for Botswana and South Africa. Furthermore, while SACU members impose common tariff rates they do not receive the revenue directly, rather the revenue is pooled and distributed according to a revenue sharing formula. Hence the revenue to each SACU member differs from that implied by the common tariff rates and the country specific imports. This requires an accounting for intra-SACU transfers that are not identified in the GTAP Data Base.

The initial shares of tariff revenue were calculated from the data in GTAP 5, wherein the total tariff revenue of the SACU region was divided amongst Botswana and South Africa in the proportions 5.57 percent and 94.43 percent respectively. ${ }^{18}$ The data base was then shocked, using the 'altertax' closure due to Malcolm (1998), to impose common tariff rates and to obtain the actual shares of tariff revenue received by Botswana and South Africa under the revenue sharing formula. The 'altertax' closure and parameter files are designed so as to minimise the effect of the shock on the data base. ${ }^{19}$ This resulted in a slight change in the revenue shares from the tariff revenue pool; Botswana's share was increased to 6.31 percent and South Africa's share decreased to 93.69 percent.

\section{Descriptive Statistics ${ }^{20}$}

It is important to appreciate some of the structural characteristics for the regions in the model's data base. The regions in the model are very different in (economic) size, Figure 1. The EU, NAFTA and Rest of the World regions each account for between 27.5 and 32 percent of global real GDP, while SADC only accounts for 0.6 percent of global GDP. Moreover, within SADC, the South Africa is dominant, accounting for 76 percent of SADC GDP while Botswana only accounts for 2.5 percent. Consequently, although this study focuses upon the 'externalities' of a specific FTA, it relates to a set of circumstances that might well be found with future PTAs. Namely a large economy, in this case the EU, negotiating a PTA with a much smaller economy,

Strictly the regions Botswana, South Africa and rest of SADC in the model do not fully identify the SADC regions because Seychelles and the Democratic Republic of Congo are excluded. It is however as near to a SADC aggregation as is possible with the GTAP 5 Data Base. one country; (b) setting the CES and CET elasticities to 1 and (c) altering the substitution (set to 0) and expansion (set to 1) parameters in the CDE system used in determining private consumption. 
in this case the RSA, who has existing trade agreements with an even smaller neighbouring economy, in this case Botswana.

\section{Figure 1 Base Period Real GDPs by Region}

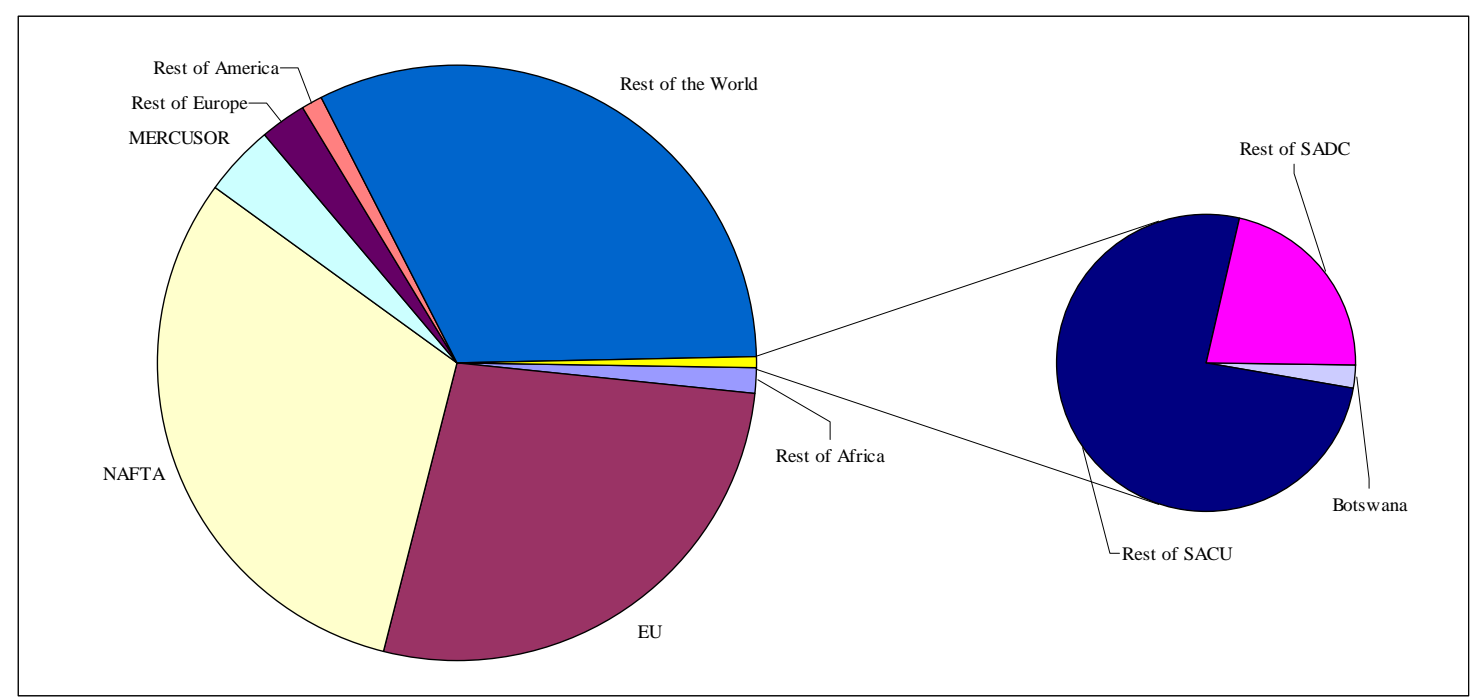

Source: GTAP Data Base

The differences in structure are not limited to size. Figure 2 provides information about the patterns of gross output for the EU and the SADC regions. From this data it is evident that Botswana is heavily dependent upon mining, with limited contributions from manufacturing, whereas the rest of SADC is more diversified, although heavily dependent upon primary commodity sectors. On the other hand South Africa has much more developed manufacturing sectors with very much less dependence upon agriculture. However, for both South Africa and the rest of SADC the 'real' size of manufacturing is arguably overstated because the heavy manufacturing sectors are typically specialised enterprises linked to the mining sectors. 
Figure 2 Gross Output Patterns for SADC Countries and EU

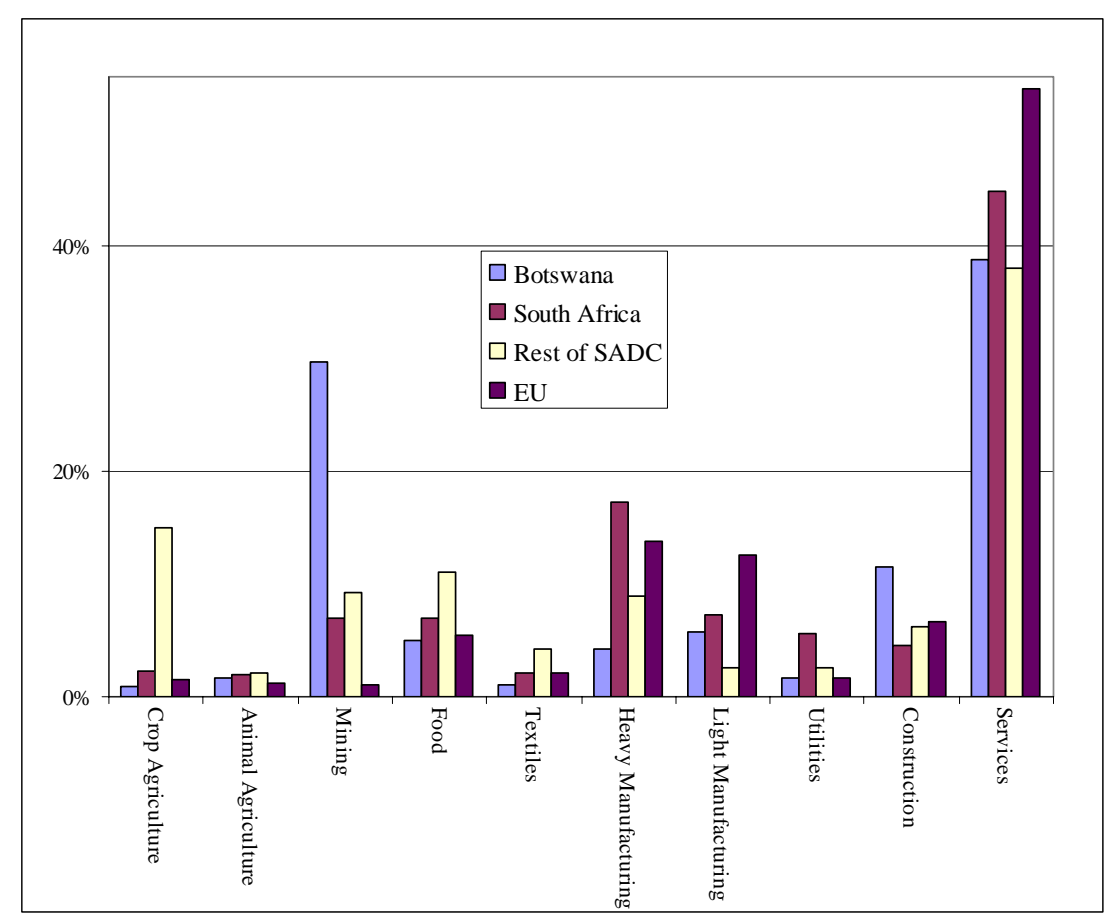

Source: GTAP Data Base

The differences in gross output structure carry over to the regional trade patterns (Figures 3 and 4). Botswana has a polarised pattern of trade with its partners. The majority of its imports, by value, (59 percent) come from South Africa, with 13 percent of imports originating in the EU, whereas the majority, 57 percent, of exports go to the EU, with a further 19 percent going to the rest of Europe, and only 13.6 percent going to South Africa. Moreover Botswana's imports are primarily manufactured commodities while mining commodities dominate its exports. South Africa's trade is much more diversified, although the EU is the largest trade partner, 44 percent of imports and 35 percent of exports, with the rest of the world also accounting for substantial shares. Botswana only accounts for 1.3 percent of South Africa's imports and 3.6 percent of her exports. South Africa's exports and imports are dominated by manufacturing commodities, albeit the exports of heavy manufacturing depend, to some extent, on domestic mining activities. 


\section{Figure 3 Trade Patterns for Botswana and South Africa by Regional Partners}

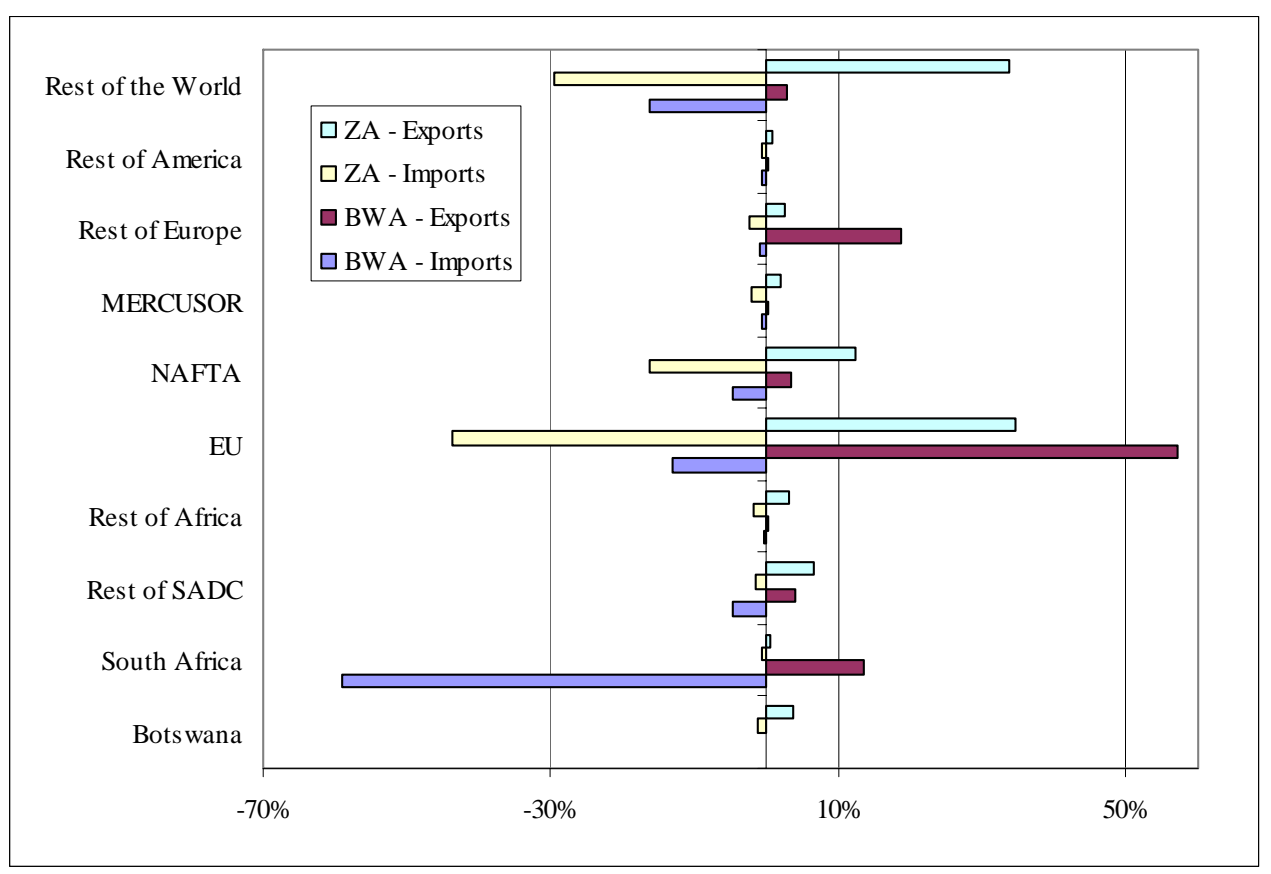

Source: GTAP Data Base

The overall picture that emerges is one in which one developed economy, the EU, is entering into a PTA with a middle income economy that has well developed manufacturing capabilities with limited exports of food and agricultural commodities, the RSA, but that is in a customs union with a middle income economy that is dependent upon exports of primary products and imports of manufactured commodities, Botswana. Moreover the SACU has a regional agreement with economies that are much poorer and have even smaller manufacturing sectors and are dependent upon exports of primary commodities. Leaving aside the PTA with the EU, it is tempting to argue that the RSA might represent a potential 'hub' for a SADC wide PTA. 21 However once a PTA between the EU and RSA comes into being it is an open question as to how this might affect regional development in southern Africa. 


\section{Figure 4 Trade Patterns for Botswana and South Africa by Commodities}

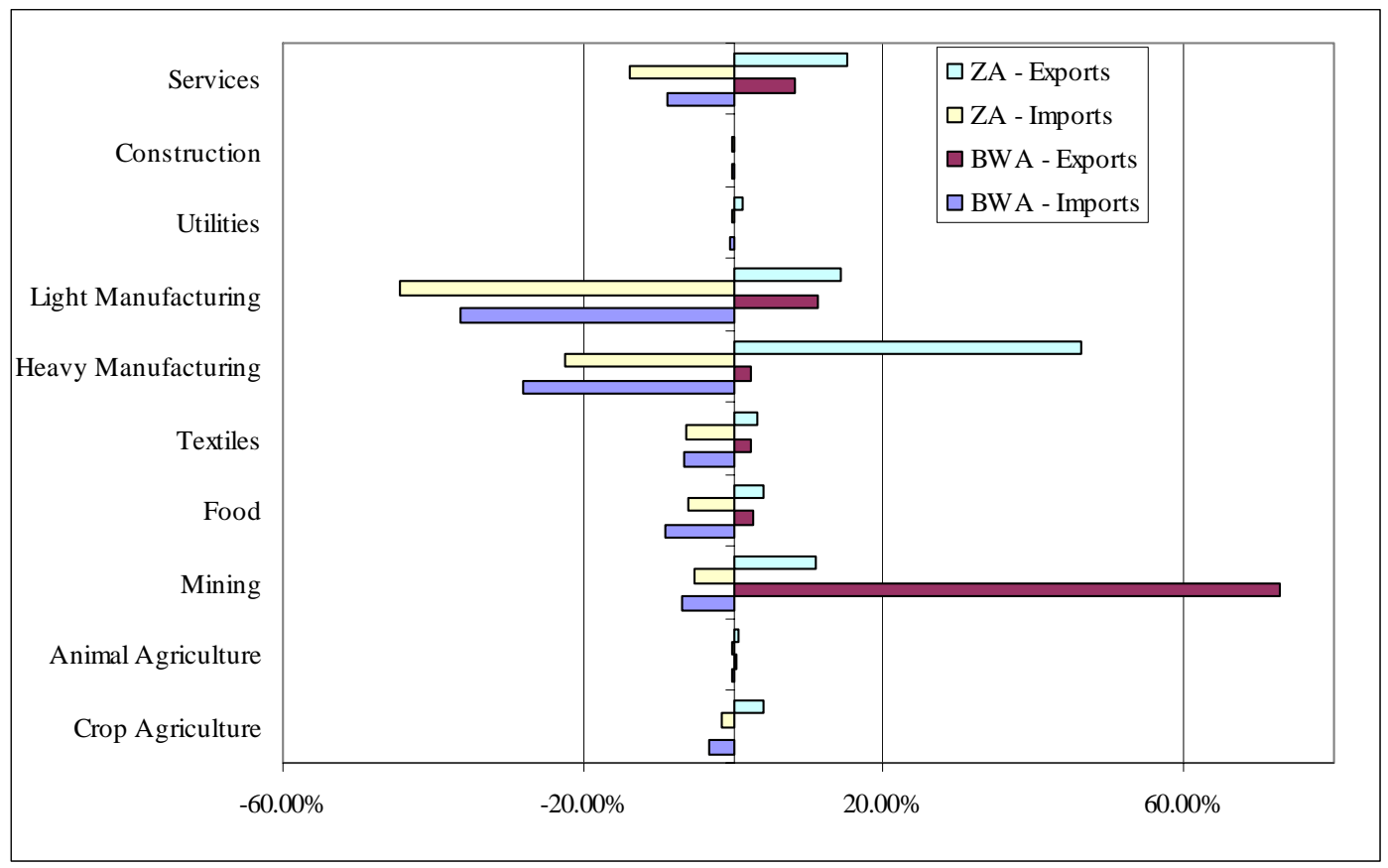

Source: GTAP Data Base

\section{$\underline{\text { Model }^{22}}$}

The model used for these analyses is an adaptation of the standard GTAP comparative static CGE model. Since descriptions of that model are widely available, e.g., Hertel and Tsigas (1997), the comments here will refer to the model closure rules, which depart from those in the standard GTAP model, and a change in the basic model.

The standard GTAP model contains the assumption that all tariff revenues 'earned' by a country accrue directly to that country. But, while SACU members impose common tariff rates they do not receive the revenue directly; rather the revenue is pooled and distributed according to a revenue sharing formula. Hence there are intra-country transfers of tariff revenues, which are not recorded in the data base, and that are subject to change with changes in tariff rates. Hence a tariff revenue pool was created in the model that gathered together all tariff revenues 'earned' in SACU and then distributed those revenues using the revenue sharing formula.

\section{Closure}

The second major change is a set of adjustments to the model closure rules (see Pyatt, 1988, on closure rules). The standard closure rules for the GTAP model were adjusted to provide a better reflection of the economies in southern Africa. Three fundamental changes were made to the closure: the first was related to fixing the trade balance, the second to employment of unskilled labour and the third to the prices and quantities on the world market of certain special commodities.

The model and associated data are available from the authors as a version of RunGTAP. 
1) The trade balance for Botswana was fixed so as to mirror the policy of running a trade surplus. The purpose of this is to counter the effects of large diamond exports. Since diamond exports account for about 35 percent of world production, and an even larger proportion of gem quality production, it might be expected that Botswana would face a downward sloping export demand curve. However, Botswana is a core member of the Central Selling Organisation (CSO) ${ }^{23}$ and therefore both the price and quantity of diamond exports are effectively fixed, and hence are fixed in the model (see point 3 below). In examining the EU RSA FTA the ratio of the trade balance to income was fixed for all the African economies and the rest of world. In order to fix the ratio of the trade balance to income savings were allowed to change as a proportion of income.

2) Alterations were also made to more accurately reflect the labour markets of the African economies (and also the Rest of World). In these countries there is typically an excess supply of unskilled labour, which can be drawn on by industries in the event of increased production. Hence, an assumption of full employment is inappropriate for these countries. In all the African regions and the rest of world the real wage rate was fixed exogenously and the supply of labour was endogenised. This allowed us to take account of the effect on unemployment within Africa of the EU RSA FTA.

3) The final group of changes made to the standard GTAP closure relate to specific industries in the Botswana economy; including the mining industry, animal products and crops. Each of these is discussed in turn below:

i) While Botswana is a large producer of diamonds the price and quantity of diamond exports are effectively fixed through Botswana's membership of the CSO. This is captured by fixing the quantity and price (fob) of diamond exports to all regions. It could be argued that it is also appropriate to restrict tightly the input substitution possibilities in diamond production, e.g., to impose the assumption of Leontief production technologies. This additional restriction was tried in some simulations but made no substantive difference to the results; hence results are only reported for simulations that did not impose Leontief technologies.

ii) Similarly Botswana has a long-standing preferential trade agreement with the EU under the auspices of the Lomé Convention, whereby fixed quantities of chilled, boneless beef can be exported duty free to the EU. To partially capture this relationship the quantity and price of processed from products from Botswana to the EU were fixed. ${ }^{24}$

iii) Finally, Botswana is dependent on crop imports and, for climatic reasons, cannot realistically expand crop production; the possibility of export of crops from Botswana was also excluded. Halving the input substitution elasticities 
captured the low potential and limited capacity for diversification in Batswana agriculture. 25

The analyses have included variations in these closure rules. The results from these explorations indicate that the results from these analyses are sensitive to the choice of closure rules; in particular the assumption of excess supplies of unskilled labour. The implications of such variations in closure are not explored further in this paper, but the results derived to date are indicative of the potential importance of the choice of closure rules to the results derived from GTAP based models for the implications of policy changes for developing regions.

\section{Analysis}

\section{Policy Experiments}

The main policy experiment for which results are reported below is very simple; full liberalisation of trade between the EU and the RSA is implemented in a single step. This policy experiment amounts to making an assumption that an EU RSA FTA actually means free trade between the countries; which it might reasonably be concluded was the RSA's desired outcome. Since Botswana is part of the SACU, it is assumed that trade liberalisation between the EU and RSA will equate to the elimination of import duties between the EU and Botswana, but that there will be no reciprocal elimination of import duties by the EU on trade with Botswana. This asymmetry in the liberalisation of trade between the EU and Botswana is an important part of the analyses. The analyses are comparative static; hence the analyses do not address potentially important questions relating to the sequencing of reforms and potential dynamic benefits from trade liberalisation.

An important consideration is the treatment of the distribution of the tariff revenue pool. The proportions distributed to each member of the SACU are assumed fixed throughout the simulation period.

But, the EU has historically been reluctant to liberalise its food and agricultural trade, and indeed most of the stumbling blocks prior to the signing of the EU RSA FTA seemed to involve discussions about the extent to which food and agricultural trade, especially trade in wine and related products, would be fully liberalised. Hence an additional series of experiments are reported for an experiment in which food and agricultural trade was only partially (50 percent) liberalised. ${ }^{26}$ The intention with these experiments was to consider the degree to which the liberalisation of agricultural and food trade influenced the impacts of the EU-RSA FTA.

\section{$\underline{\text { Results }}$}

The real GDP changes, Figure 5, suggest that the beneficiaries of the EU RSA FTA will be the EU (0.004 percent or \$(US) 344m of GDP) and South Africa (1.2 percent or \$(US) $1670 \mathrm{~m}$ of GDP). These results reflect the relatively high proportion of South African trade accounted for by the EU, and the relative lower proportion of EU trade accounted for by South Africa. There are clear suggestions of a 'beggar thy neighbour outcome' through the negative impacts of the FTA

25 The experiments were also run with the input substitution elasticities for crop agriculture set at one quarter of the base levels. While this damped down the response by crop agriculture in Botswana the difference was small.

A 50 percent reduction in tariffs between the EU and RSA was assumed for crop agriculture, animal agriculture and food. Most of the exemptions in the EU-RSA FTA actually refer to commodities in the food aggregate. 
on the Rest of SADC. Moreover there are negative impacts on all the other regions. In relative terms the reductions in GDP are greatest for the SADC region.

The estimated welfare changes, equivalent variations, (the first column of results in Table 3) display the same pattern of benefits, but, because they are expressed in money metric welfare form, serve to highlight the absolute magnitude of the estimated benefits. Botswana experiences a decrease in welfare, which is made up of minor gains from allocative efficiency and the change in the price of capital goods that are offset by negative terms of trade and endowment effects where the endowment effect reflects a 0.1 percent decline in the use of unskilled labour in Botswana. 27 But the dominant factor is the reduction in revenue from the tax pool. ${ }^{28}$ Clearly the operation of the tax pool, which is central to the operation of SACU, is a substantial component of the welfare implications for Botswana. Moreover, since the operation of the tax pool can be adjusted by the member states of SACU, it would be possible to adjust the tax pool arrangements to counter these adverse welfare implications. Indeed the magnitudes of the welfare gains to South Africa and the EU, \$(US) $1729 \mathrm{~m}$ and $\$(\mathrm{US}) 797 \mathrm{~m}$ respectively, are such as to indicate that the costs of compensation would be minimal.

\section{Figure 5 Changes in Real GDP (\%)}

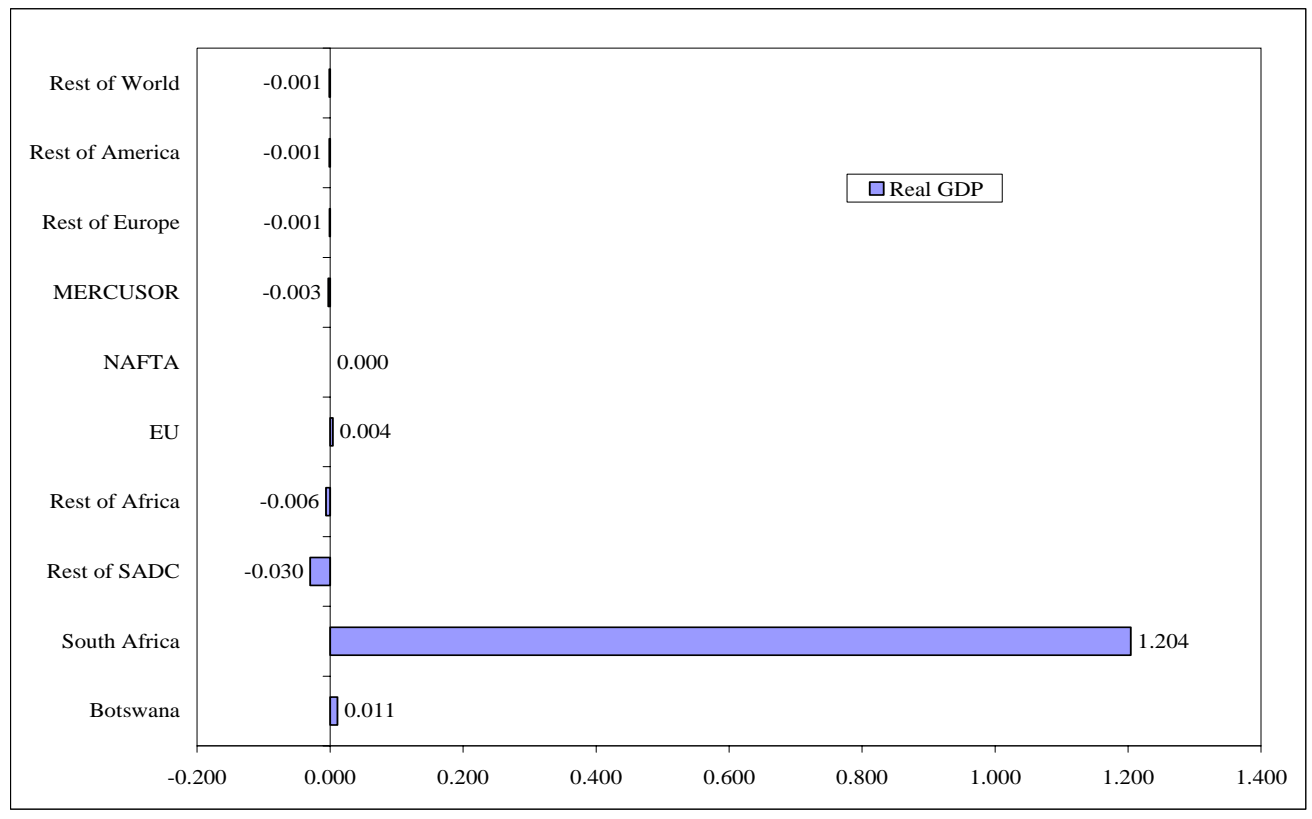

Source: Model Estimates

The decompositions of the welfare gains to the EU and South Africa well illustrate the contrasting nature of the gains. South Africa gains primarily through the growth in employment of unskilled labour of 2.6 percent, (the endowment effect) and improvements in allocative efficiency, while the EU benefits through the terms of trade and allocative efficiency effects. For neither region are the other components of the welfare decomposition substantial components of the change in welfare. The welfare decompositions for all the other regions, illustrate a strong

27 The endowment effects can only be non-zero for regions with 'surplus' factors.

28 The tax pool effect only impacts upon members of the SACU revenue pool. Note that while the nominal transfers and receipts associated with the tax pool are identical the welfare effects differ because of differences in preferences between South Africa and Botswana. 
terms of trade effect. For those regions, other than Botswana and South Africa, where the assumption of surplus unskilled labour is imposed (Rest of SADC, Rest of Africa and Rest of the World) the endowment effect is also a significant component of the negative impact on welfare, i.e., significant proportion of the adverse impact on other 'developing' regions arises primarily from reductions in the employment of unskilled labour.

Table 3 Welfare decomposition (\$US) - Full Liberalisation

\begin{tabular}{|c|c|c|c|c|c|c|c|}
\hline & $\begin{array}{l}\text { Welfare } \\
\text { (\$USm) }\end{array}$ & $\begin{array}{l}\text { Allocative } \\
\text { Efficiency }\end{array}$ & $\begin{array}{c}\text { Capital } \\
\text { goods } \\
\text { effect } \\
\end{array}$ & $\begin{array}{c}\text { Endowment } \\
\text { Effect }\end{array}$ & $\begin{array}{c}\text { Terms of } \\
\text { Trade } \\
\text { Effect } \\
\end{array}$ & $\begin{array}{c}\text { Tax } \\
\text { Pool } \\
\text { Effect } \\
\end{array}$ & Other $^{\mathrm{a}}$ \\
\hline Botswana & -71.5 & 1.6 & 10.4 & -1.1 & -4.6 & -77.8 & -0.1 \\
\hline South Africa & 1729.5 & 350.0 & 39.4 & 1318.9 & -66.5 & 77.6 & 10.1 \\
\hline Rest of SADC & -14.2 & -4.5 & 0.8 & -7.4 & -3.1 & 0.0 & 0.0 \\
\hline Rest of Africa & -37.5 & -8.8 & -1.5 & -13.9 & -13.4 & 0.0 & 0.0 \\
\hline EU & 797.2 & 343.9 & -23.9 & 0.0 & 477.1 & 0.0 & 0.0 \\
\hline NAFTA & -97.7 & -3.0 & -16.5 & 0.0 & -78.1 & 0.0 & 0.0 \\
\hline MERCUSOR & -97.5 & -29.7 & -16.6 & 0.0 & -51.2 & 0.0 & 0.0 \\
\hline Rest of Europe & -53.2 & -7.5 & 0.0 & 0.0 & -45.8 & 0.0 & 0.0 \\
\hline $\begin{array}{l}\text { Rest of } \\
\text { America }\end{array}$ & -23.2 & -4.7 & -4.3 & 0.0 & -14.2 & 0.0 & 0.0 \\
\hline $\begin{array}{l}\text { Rest of the } \\
\text { World }\end{array}$ & -310.9 & -70.4 & 12.3 & -52.2 & -200.6 & 0.0 & 0.0 \\
\hline $\begin{array}{l}\text { EU + South } \\
\text { Africa }\end{array}$ & 2526.6 & 693.9 & 15.5 & 1318.9 & 410.6 & 77.6 & 10.1 \\
\hline $\begin{array}{l}\text { All Other } \\
\text { Regions }\end{array}$ & -705.6 & -126.9 & -15.3 & -74.6 & -410.9 & -77.8 & -0.1 \\
\hline Total & 1821.1 & 567.0 & 0.2 & 1244.4 & -0.3 & -0.2 & 10.0 \\
\hline
\end{tabular}

a. Due to the change in preferences resulting from the fixed trade balance and endogenous savings rate.

Source: Model Estimates

Global welfare increases by (\$(US) 1811m), but this aggregate hides the extent to which the EU and South Africa gain while other regions lose. The impact of the FTA on other regions is a triple negative; substantial losses from allocative efficiency (-\$(US) 126.9m) and terms of trade ($\$($ US $) 410.9 \mathrm{~m}$ ) effects and through reductions in the employment of unskilled labour (-\$(US) 74.6m), while the EU and South Africa gain on each account, although the proportions differ between the allocative efficiency, endowment and terms of trade effects.

The real GDP and welfare decomposition results hint at the fact that the patterns of gains and losses may be more complex than these simple aggregate measures indicate; that is indeed the case. It is important to note the assumptions implicit to the comparative static method of analysis. 
When deriving the results it is assumed that all the regions have optimised to the new set of (price) incentives and hence that all the indicated resource shifts have taken place. When the aggregate results suggest that the changes in GDP and welfare are proportionately small, as they do here, and in other studies of trade liberalisation and integration (see Robinson and Thierfelder, 1999), it is tempting to assume that the processes of adjustment implied by the aggregate results are also relatively small. If the required processes of adjustment are not small, then it is wise to consider them in assessing the actual costs and benefits of adjusting. Moreover for many African economies the processes of adjustment can be both slow and costly, as the experience of World Bank and IMF sponsored structural adjustment programmes has indicated.

\section{Figure 6 Changes in Sectoral Value Added (\%)}

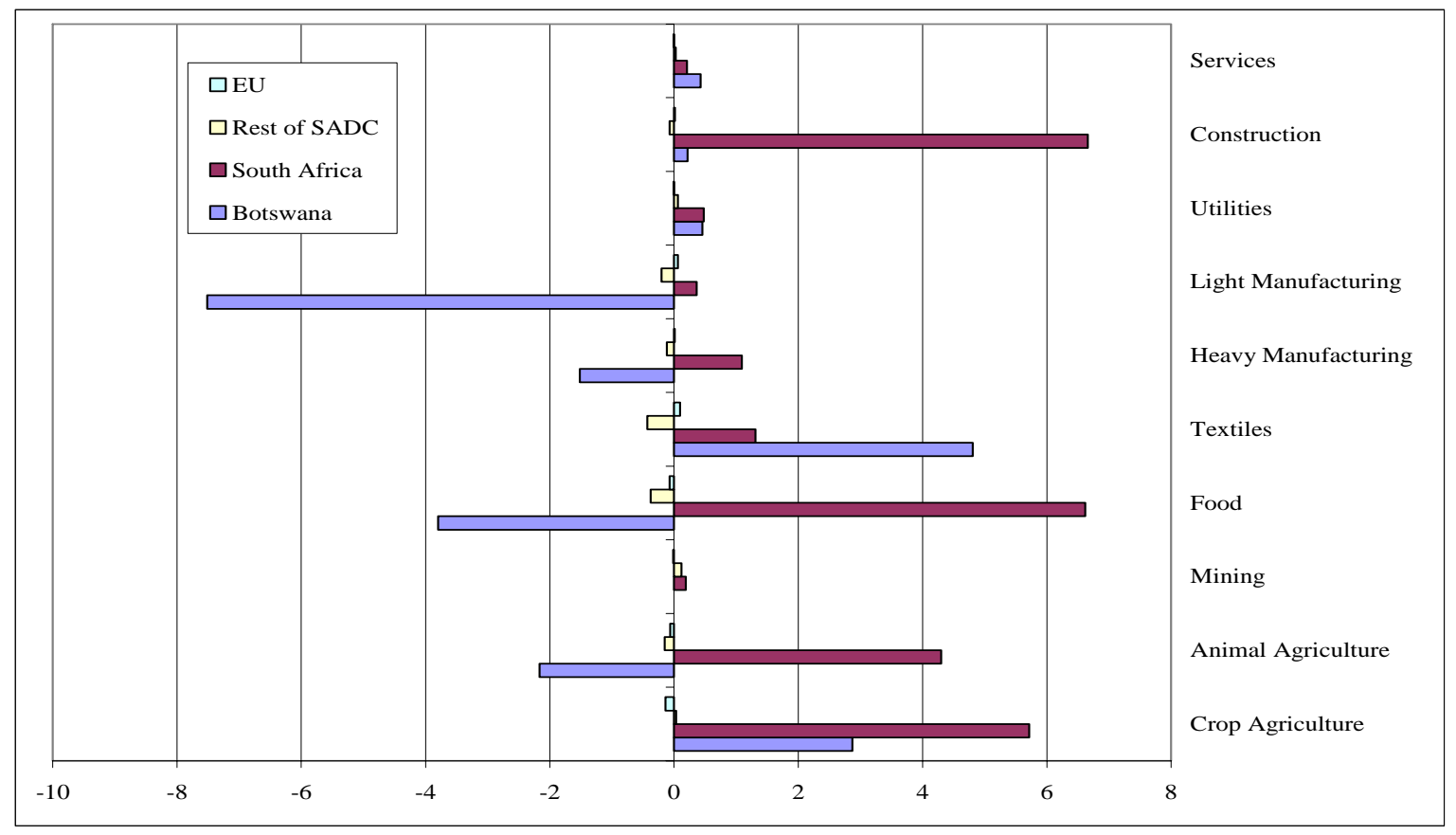

Source: Model Estimates

Some indication of the extent of adjustment associated with the small changes in real GDP and welfare can be gleaned from the changes in sectoral value added; see Figure 6, which reports proportionate changes in sectoral value added for the EU and SADC regions. It is immediately apparent that there are large incentives to reallocate resources in Botswana and South Africa. Botswana should move resources from animal agriculture, food and light and heavy manufacturing to crop agriculture and textiles, while South Africa should move resources into crop and animal agriculture, food and construction. For all commodities the changes predicted for the EU are all minimal, indeed for no sector does the change in value added exceed 0.14 percent; the largest effects are -0.139 and 0.096 percent for crop agriculture and textiles respectively. In contrast for the Rest of SADC the only noticeable positive effect is for mining ( 0.117 percent), whereas there are clear negative incentives (ranging from -0.43 to -0.07 percent reductions in value added) across all the manufacturing sectors. 
Table 4 Changes in Commodity Exports (\$USm)

\begin{tabular}{lcccc}
\hline & Botswana & South Africa & Rest of SADC & EU \\
\hline Crop Agriculture & 0.00 & 277.24 & 10.44 & -111.36 \\
Animal Agriculture & 0.73 & 18.30 & 0.22 & -0.33 \\
Mining & 0.00 & -63.20 & 7.56 & -17.03 \\
Food & -10.42 & 2123.37 & -28.94 & 413.83 \\
Textiles & 3.98 & 197.47 & -8.79 & 300.30 \\
Heavy Manufacturing & -1.26 & 425.30 & -5.96 & 249.88 \\
Light Manufacturing & -28.93 & 502.16 & -3.29 & 1231.63 \\
Utilities & 0.10 & -4.17 & 1.07 & -12.42 \\
Construction & 0.31 & 0.34 & 0.25 & -15.88 \\
Services & 8.46 & 14.37 & 12.43 & -400.16 \\
\hline
\end{tabular}

Source: Model Estimates

These results are suggestive of substantial structural changes post the EU RSA FTA. While these changes are most substantial for Botswana and South Africa, those for the Rest of SADC are not insubstantial. In combination they are large enough to suggest the requirement for an appreciable transformation process in southern Africa before equilibrium is re-established. Furthermore the changes in commodity output and value added are suggestive of forces moving the economies of southern Africa away from manufacturing towards food production, both directly from within agriculture and through food processing activities. For regions with legitimate aspirations to diversify their economies and industrialise, these results represent outcomes that are unlikely to be deemed politically attractive.

Table 5 Changes in Commodity Imports (\$USm)

\begin{tabular}{lcccc}
\hline & Botswana & South Africa & Rest of SADC & EU \\
\hline Crop Agriculture & -3.10 & 74.83 & -3.89 & 149.30 \\
Animal Agriculture & -0.54 & 13.90 & -0.43 & 7.86 \\
Mining & 0.38 & 6.76 & -0.38 & 1.69 \\
Food & 3.15 & 1440.19 & -2.01 & 1111.86 \\
Textiles & 2.45 & 188.38 & -0.21 & 169.56 \\
Heavy Manufacturing & -10.07 & 586.95 & -3.48 & 320.13 \\
Light Manufacturing & 2.54 & 1497.58 & -3.62 & 617.31 \\
Utilities & -0.19 & 0.03 & -0.76 & 5.19 \\
Construction & -0.12 & 1.73 & -0.11 & 11.06 \\
Services & -2.84 & 14.02 & -5.79 & 254.34 \\
\hline
\end{tabular}

Source: Model Estimates 
The trade results (Tables 4 and 5) indicate why South Africa might be enthusiastic about the EU RSA FTA; strong export growth is indicated for animal agriculture, textiles and light manufacturing and exceptionally strong growth for food. Similarly the results indicate that the EU will experience substantial export growth in manufactured commodities. It is however noticeable that the EU's export growth is concentrated in non-food manufactured commodities while South Africa's export growth is heavily concentrated in food exports. This pattern carries over to direct agricultural exports where the EU experiences reduced crop exports while South Africa experiences appreciable growth. For Botswana minimal growth in the exports of services and textiles are indicated with declining exports of food and light manufacturing, whereas for the Rest of SADC manufacturing exports decline and agricultural exports increase.

Figure 7a Factor Demand by Activity for Botswana

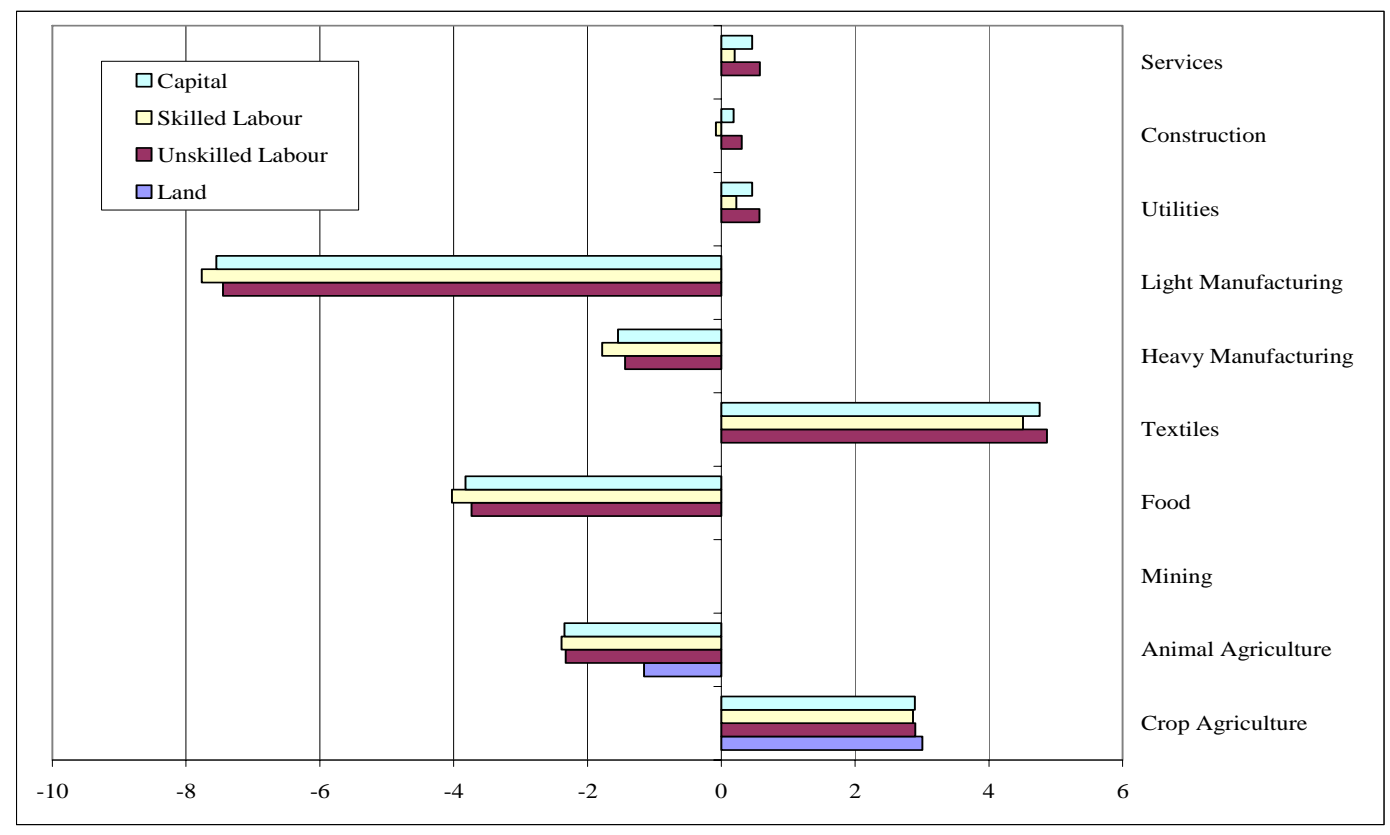

Source: Model Estimates

On the import side, food and manufacturing imports to South Africa and the EU increase substantially, while there is an across the board decline in imports to the Rest of SADC and only food and textiles imports to Botswana increase. As with the changes in the patterns of exports, the changes in imports by the EU and South Africa are indicative of appreciable differences in the sectoral impacts of the EU RSA FTA upon the signatories. Thus while the benefits for the EU and South Africa are appreciable, the impacts upon Botswana and the Rest of SADC indicate that they may be much less enthusiastic about the EU RSA FTA. 


\section{Figure 7b Factor Demand by Activity for South Africa}

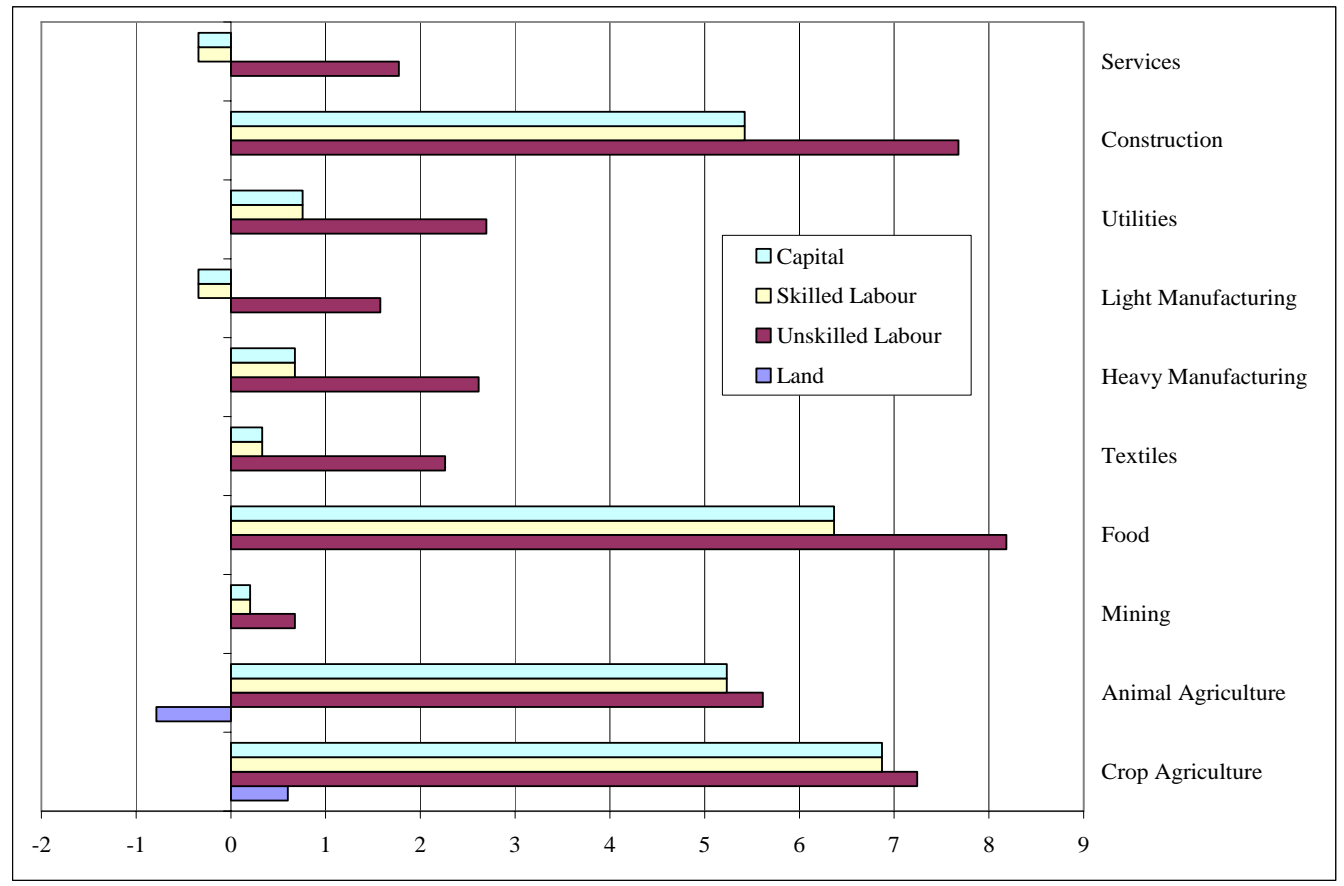

Source: Model Estimates

The combination of the changes in sectoral value added and trade flows suggest that the EU RSA FTA will result in substantial changes in the patterns of incentives across Africa. Despite the small (relative) changes in GDP and welfare, Botswana, South Africa and the Rest of SADC are predicted to experience substantial adjustments in the patterns of factor demand, see Figures $7 \mathrm{a}$, 7b and 7c. Such substantial changes in the patterns of employment would understandably raise concerns in Botswana, especially in light of the declining employment in manufacturing industries, except textiles, and the decline in total employment of unskilled labour (-0.1 percent). On the other hand South Africa might be more sanguine; the substantial increases in employment in agriculture, food and construction would offset the relatively small declines in employment by light manufacturing, mining and services and there is a useful boost in total employment of unskilled labour (2.6 percent). Moreover, the substantial increases in agricultural employment might assist with rural income redistribution objectives since much of the employment growth is in agriculture. The changes for the Rest of SADC are all relatively minor, but also indicate a move of employment away from manufacturing that may not be welcomed by governments. The changes in employment patterns for the EU are all small in proportionate terms but indicate how the FTA would reduce employment in food and agriculture while expanding employment in manufacturing. 
Figure 7c Factor Demand by Activity for Rest of SADC

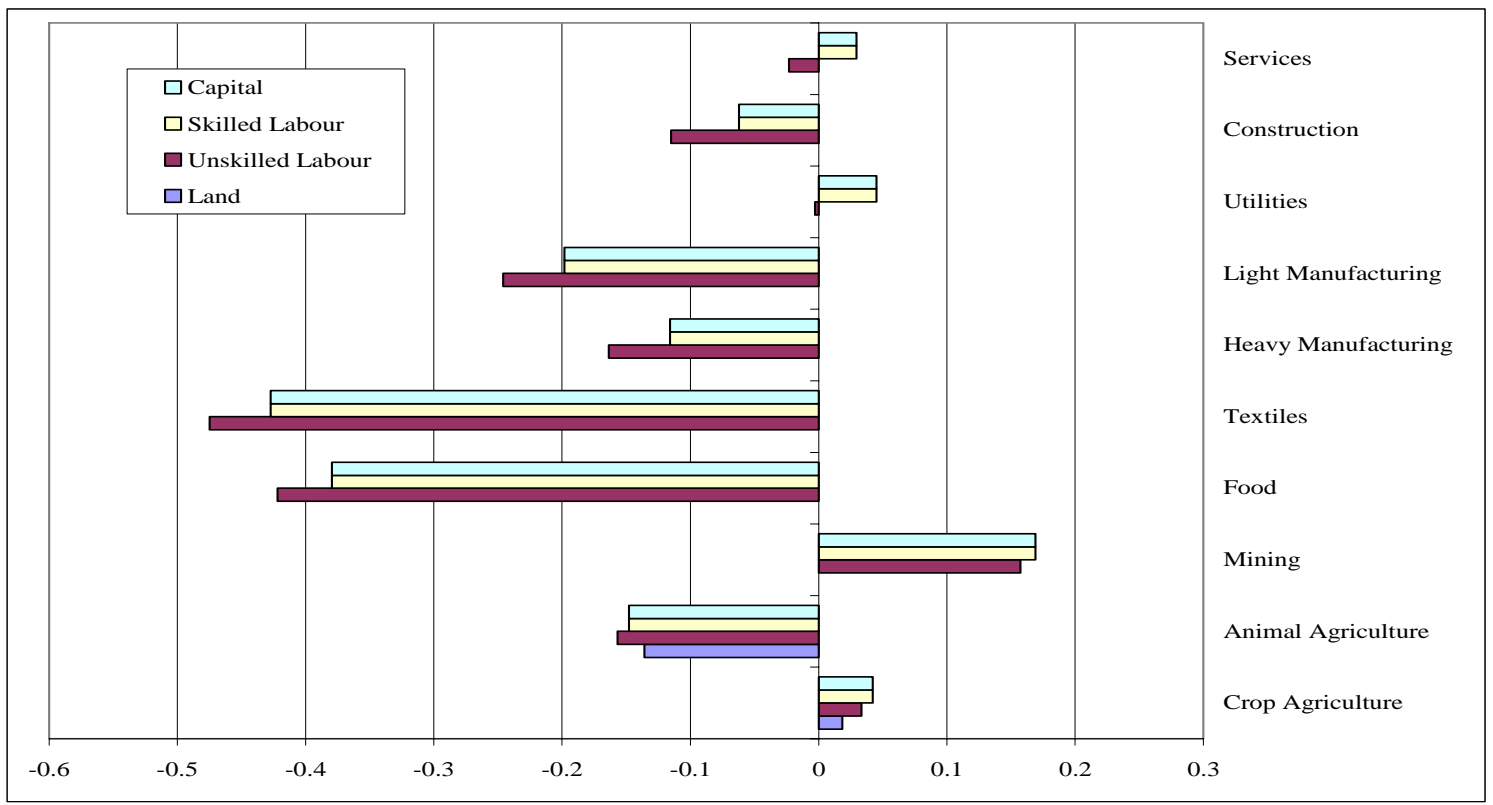

Source: Model Estimates

Figure 7d Factor Demand by Activity for the EU - Full Liberalisation

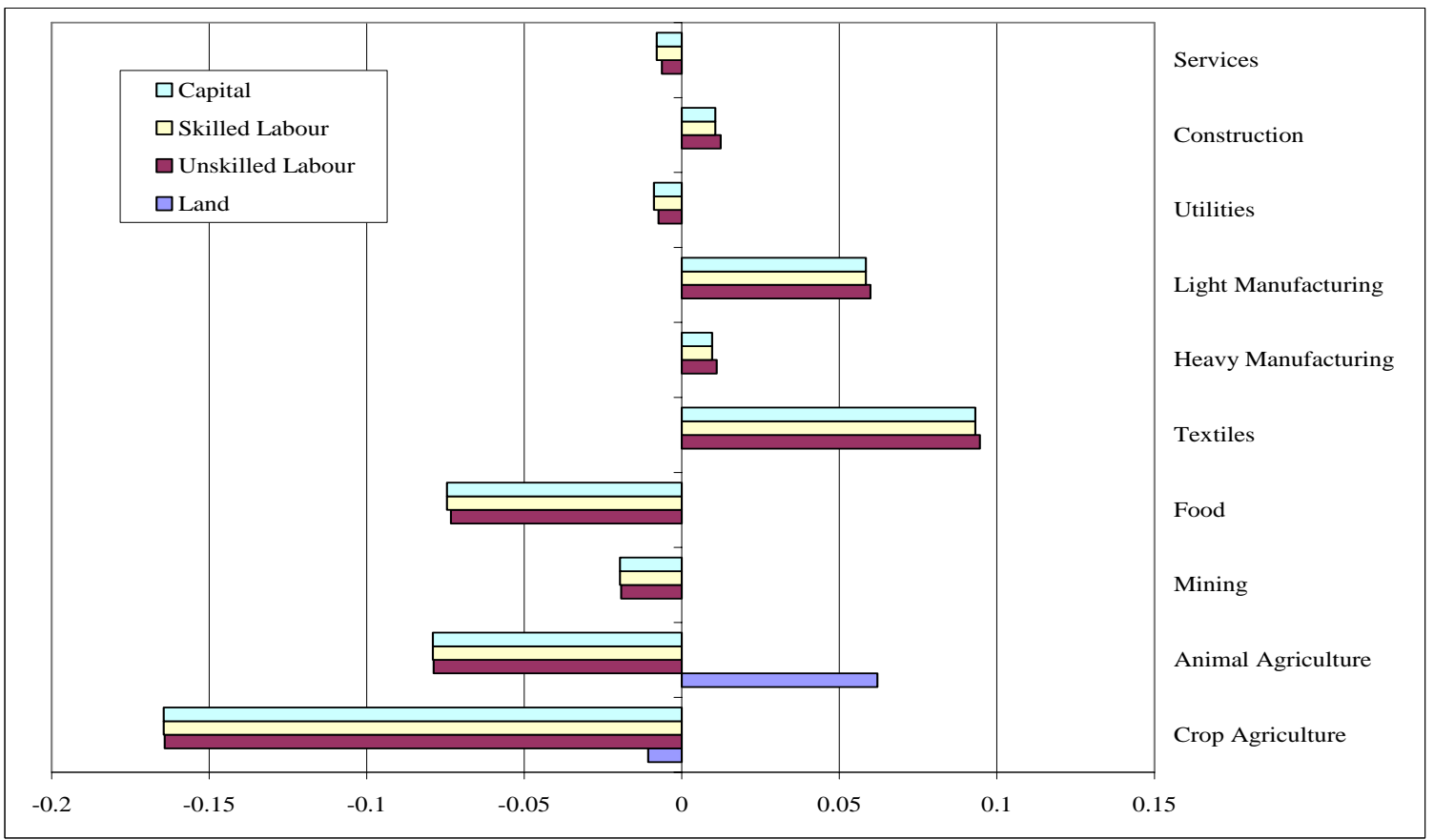

Source: Model Estimates 
Historically the EU has been reluctant to engage in a 'genuine' FTA, but rather has preferred to engage in preferential trade agreements that do not involve substantive reductions in the support provided to the European agricultural and food industries under the CAP. It is clear from the information that is available about the details of the EU RSA FTA that this trade agreement has also involved only a partial liberalisation of food and agriculture trade between the partners. The results for the EU provide some indication of why the EU has been reluctant to liberalise trade in food and agriculture; employment in agriculture and food will decline while food and agriculture imports increase and agricultural exports decrease, although food exports will expand. On the other hand the results for South Africa indicate why South Africa would very much want a liberalisation of the food and agriculture trade with the EU; food and agriculture imports and exports expand appreciably, with the increase in exports substantially exceeding the increase in imports, and there are matching increases in employment in food and agriculture. It is consequently instructive to examine how the apparent gains from an EU RSA FTA would be affected by a partial liberalisation of trade in food and agriculture. Here a partial liberalisation is defined as a 50 percent cut in tariffs on food and agricultural commodities, with a 100 percent reductions on other commodities. The results are discussed briefly below.

\section{Figure 8 Changes in Real GDP (\%) - Partial Liberalisation}

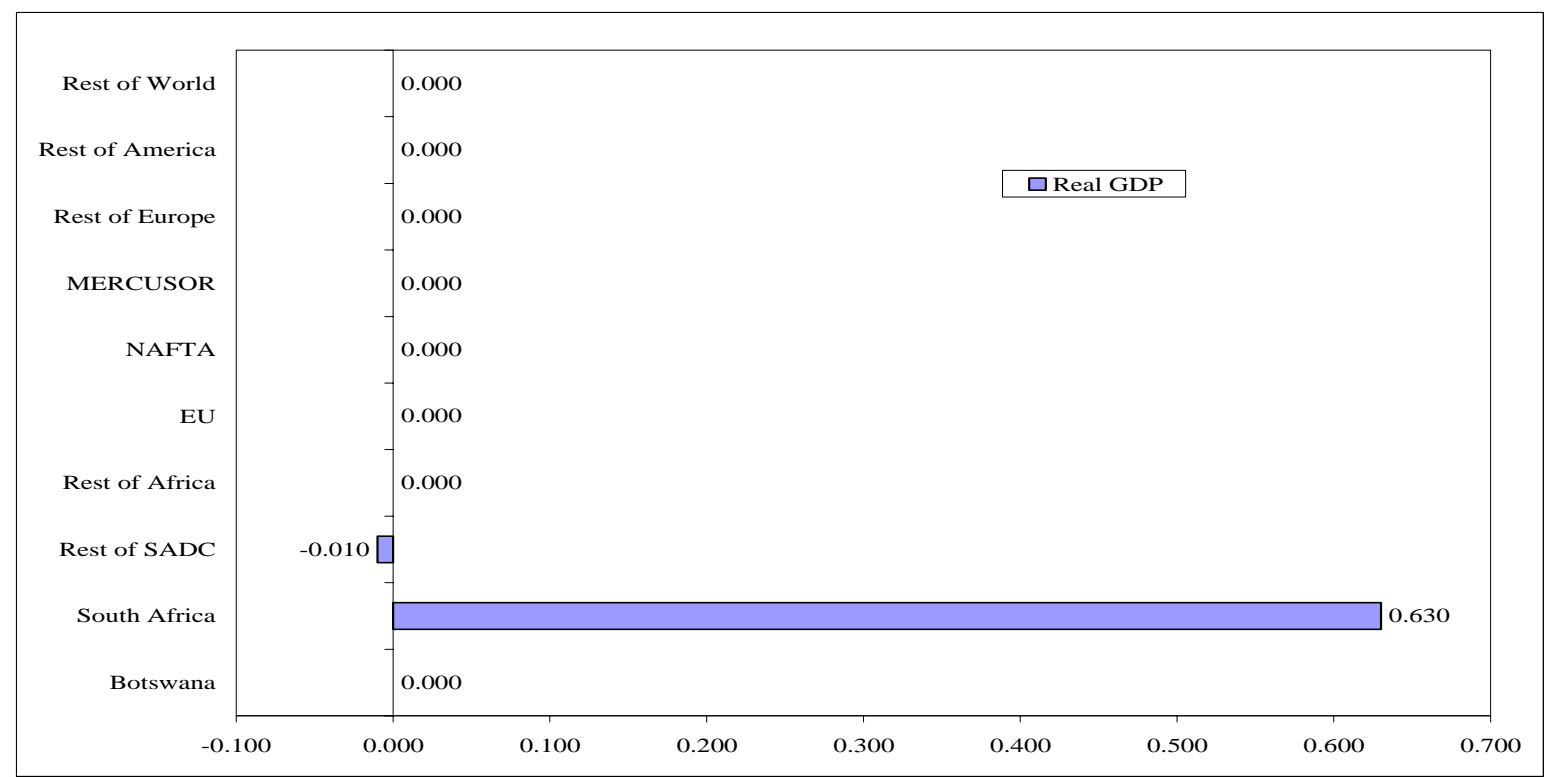

Source: Model Estimates

It is evident from the results for a full liberalisation of trade between the EU and South Africa that a substantial proportion of the gains for South Africa come from expansions in the food and agriculture sectors, both in terms of trade flows and employment. Partial liberalisation reduces the GDP gain for South Africa from 1.2 percent to 0.63 percent while very marginally reducing the gain for the EU (0.0043 to 0.0038 percent). This reflects the substantial differences in the sectoral patterns of gains and losses for the EU and South Africa. Those sectors of South Africa's economy that grow with full liberalisation experience less growth while the reverse applies in the EU. On the other hand, while the positive GDP impact on Botswana increases slightly, there is 
little amelioration of the negative impacts of the EU RSA FTA upon other regions. More interesting are the welfare implications. The gross benefits to the EU and South Africa decline by some 38 percent, but South Africa's welfare gain declines by 54 percent while the EU's welfare gain decreases by only 3 percent. The key component of the loss to South Africa is the reduction in the endowment effect, which accounts for two thirds of the reduction in potential welfare gains. Since the endowment effect arises from the increases in the employment of unskilled labour, a key implication of a partial liberalisation is that South Africa fails to realise approximately 50 percent of the employment boost that could have been achieved with full liberalisation.

Table 6 Welfare decomposition (\$USm) - Partial Liberalisation

\begin{tabular}{lccccccc}
\hline & Welfare & Allocative & $\begin{array}{c}\text { Capital } \\
\text { (\$USm) } \\
\text { Efficiency } \\
\text { effect }\end{array}$ & $\begin{array}{c}\text { Endowment } \\
\text { Effect }\end{array}$ & $\begin{array}{c}\text { Terms } \\
\text { of } \\
\text { Trade } \\
\text { Effect }\end{array}$ & $\begin{array}{c}\text { Tax } \\
\text { Pool } \\
\text { Effect }\end{array}$ & Other $^{\mathbf{a}}$ \\
\hline Botswana & -42.9 & 0.4 & 10.7 & -0.4 & 0.2 & -53.7 & -0.1 \\
South Africa & 792.9 & 161.4 & 44.1 & 708.7 & -182.6 & 53.6 & 7.5 \\
Rest of SADC & 4.6 & -2.5 & 0.8 & -0.7 & 7.0 & 0.0 & 0.0 \\
Rest of Africa & -20.1 & -4.4 & -1.0 & -6.9 & -7.8 & 0.0 & 0.0 \\
EU & 770.5 & 301.7 & -27.4 & 0.0 & 496.1 & 0.0 & 0.0 \\
NAFTA & -91.4 & -6.5 & -17.9 & 0.0 & -67.0 & 0.0 & 0.0 \\
MERCUSOR & -49.9 & -16.0 & -9.1 & 0.0 & -24.8 & 0.0 & 0.0 \\
Rest of Europe & -51.2 & -10.1 & -0.4 & 0.0 & -40.7 & 0.0 & 0.0 \\
Rest of America & -11.6 & -2.0 & -2.6 & 0.0 & -7.0 & 0.0 & 0.0 \\
Rest of the World & -346.2 & -69.7 & 2.9 & -105.2 & -174.2 & 0.0 & 0.0 \\
\hline EU + South & & & & & & & \\
Africa & 1563.3 & 463.2 & 16.7 & 708.7 & 313.6 & 53.6 & 7.5 \\
All Other Regions & -608.7 & -110.9 & -16.5 & -113.1 & -314.4 & -53.7 & -0.1 \\
\hline Total & 954.6 & 352.3 & 0.2 & 595.6 & -0.8 & -0.1 & 7.4 \\
\hline
\end{tabular}

a. Due to the change in preferences resulting from the fixed trade balance and endogenous savings rate.

Source: Model Estimates

Partial liberalisation damps down the negative welfare implications for all other regions that stem from the EU RSA FTA; hence the 'beggar thy neighbour' effects are reduced. The change in global situation is most striking. While the aggregate negative impact of the welfare of regions other that the EU and South Africa decline (by $\$(U S) 96.9 \mathrm{~m}$ ), the positive welfare effects for the EU and South Africa decline even further (by \$(US) 963.3m); hence the global impact is negative (-\$(US) 866.4m). The vast majority of the impact comes through the reduced endowment effect 
in the South Africa. These results indicate that a partial liberalisation of agricultural and food trade can only be marginally justified on the grounds of ameliorating the adverse impacts of the FTA on other regions.

Moreover this partial liberalisation does not ameliorate the structural change effects of the full liberalisation of EU RSA trade. As the changes in value added, Figure 9, indicate the implied changes in employment structure remain substantial, with the major difference being the large reductions in the growth of value added in food and agriculture for South Africa. Hence the changing patterns of incentives associated with a full liberalisation of trade remain, but at the cost of a substantial reduction in the welfare gains for South Africa.

\section{Figure 9 Changes in Sectoral Value Added (\%)-Partial Liberalisation}

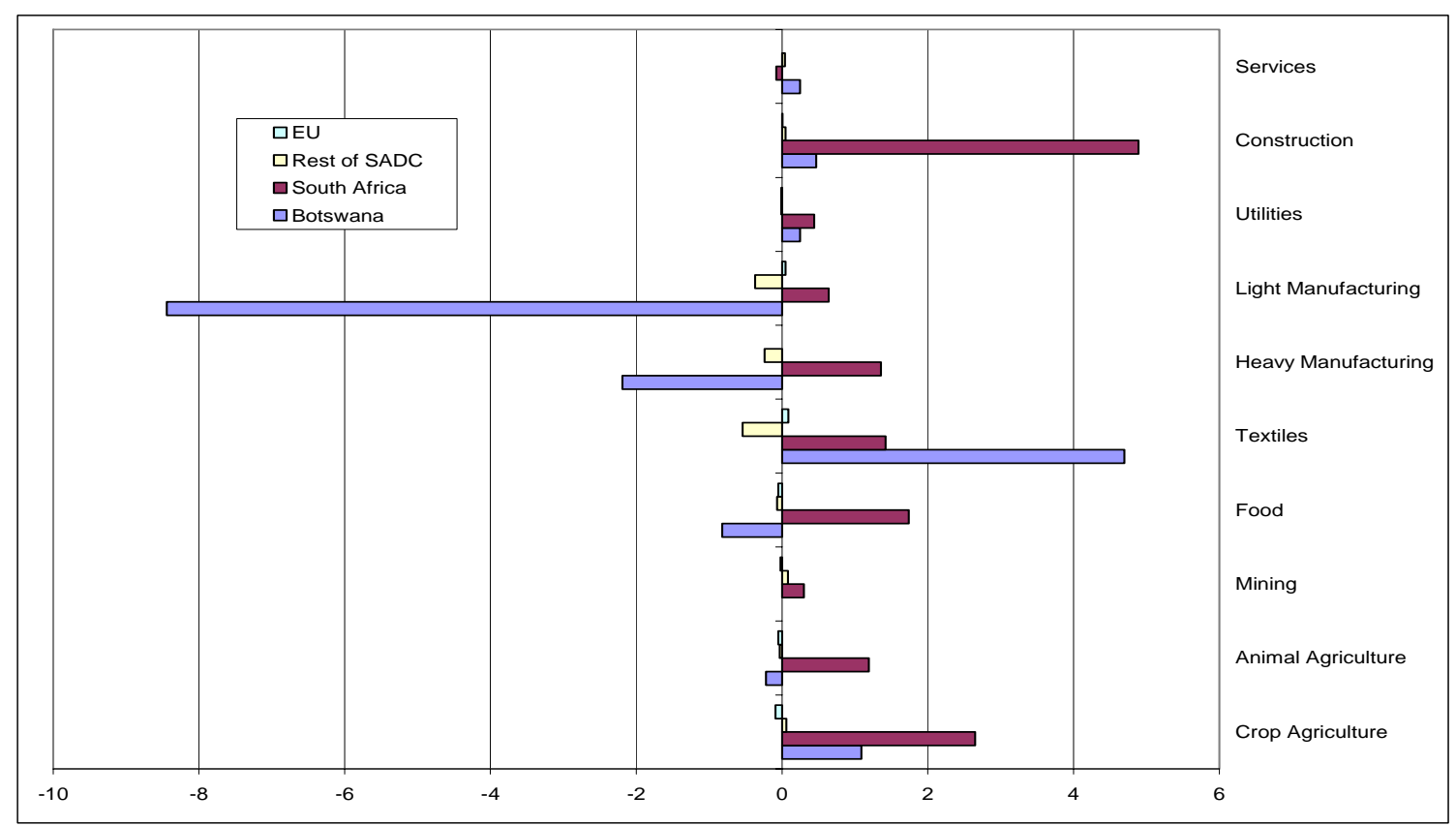

Source: Model Estimates

\section{Concluding Comments}

The EU, through the Cotonou Agreement, has committed itself to seeking a series of preferential trading agreements with the African, Caribbean and Pacific (ACP) nations that were signatories to the Lomé Conventions. This commitment is predated upon the presumption that such agreements will provide an environment within which the ACP states can prosper. As the literature on customs unions has long recognised (e.g., Lipsey, 1957 and 1960) the impacts of preferential trade agreements involve general equilibrium effects and second best considerations; hence there may be winners and losers. The analyses reported in this paper are particularly concerned with the extent to which third parties might be affected by a bilateral free trade agreement between the EU and the RSA. The results are clearly a product of the way the economic systems are modeled, and consequently may change if allowance is made for imperfect 
competition, scale economies and dynamics; these are questions that do not appear to have been addressed in a systematic and quantitative manner. Nevertheless they indicate that this bilateral agreement may have noticeable adverse consequences for nations that are not party to the FTA and are often less developed than the signatories; and that these adverse consequences are more likely to reduce than increase the well-being of the least well off in those regions. A result that runs counter to the EU's professed policies towards developing countries.

The results indicate that the EU RSA FTA will produce appreciable welfare gains for the EU and South Africa by promoting allocative efficiency in both partners' economies, employment growth in South Africa and improvements in the terms of trade for the EU. The incentives for the EU and the RSA to form a FTA are therefore clear. But these gains are acquired at the expense of the rest of the global economy, which loses out through reductions in allocative efficiency, employment and the terms of trade. These negative effects are most pronounced among the African states and in particular those states in SADC, with Botswana being the major loser. While the welfare effects are relatively small, the losses are only small if the economies of sub-Saharan Africa (SSA) can achieve appreciable structural changes, which history suggests is not an easy transformation. Moreover the structural changes that are implied involve reductions in manufacturing capacities in SSA: changes that may be politically unpopular.

The results for an FTA indicate that many of the gains for South Africa come through the expansion of food and agricultural production and trade. However, the EU RSA FTA only includes a partial liberalisation of trade in food and agricultural commodities. The results for a partial liberalisation of trade between the EU and South Africa alter the conclusions. Although South Africa still experiences a welfare gain, its value is nearly halved while the EU still experiences the same welfare gain, and South Africa's neighbours still experience major changes in the structure of incentives and either welfare losses or no gains in welfare. Moreover the reduction in the increase in the employment of unskilled labour in South Africa indicates that a major potential component of pro-poor growth in South Africa, which might be considered a desirable objective of an EU RSA FTA, is drastically reduced.

The results indicate that if the EU is serious about assisting African development through trade agreements then the EU needs to engage in comprehensive programmes of evaluation before entering into such agreements. These evaluations should identify not only the gains and losses for the immediate signatories, but also for third parties. Furthermore, the critical importance of the liberalisation of trade in food and agricultural products for the gains from a trade agreement to South Africa, coupled with the very low cost of such concessions to the EU, indicates, yet again, the importance of liberalising food and agricultural trade for developing countries. 


\section{References}

Armington, P.S., (1969). 'A Theory of Demand for Products Distinguished by Place of Production’, IMF Staff Papers, Vol 16, pp 159-178.

Binswanger, H.P. and Deininger, K., (1993). 'South African Land Policy: The Legacy of History and Current Options', World Development, Vol 21, pp 1451-1475.

Deininger, K. and Binswanger, H.P., (1995). 'Rent Seeking and the Development of Large-Scale Agriculture in Kenya, South Africa, and Zimbabwe', Economic Development and Cultural Change, Vol 43, pp 493-522.

Dimaranan, B. V. and McDougall, R., (2002). Global Trade, Assistance, and Production: The GTAP 5 Data Base, Center for Global Trade Analysis, Purdue University.

Gehlhar, M., Gray, D., Hertel, T.W., Huff, K.M., Ianchovichina, E., McDonald, B.J., MacDougall, R., Tsigas, M.E., and Wigle, R., (1997). 'Overview of the GTAP Data Base', in Hertel, T.W., (ed). Global Trade Analysis: Modeling and Applications. Cambridge: Cambridge University Press.

Hertel, T.W. and Tsigas, M.E., (1997). 'Structure of GTAP', in Hertel, T.W., (1997). Global Trade Analysis: Modeling and Applications. Cambridge: Cambridge University Press.

Lewis, J.D., (2001). 'Reform and Opportunity: The Changing Role and Patterns of Trade in South Africa and SADC', Africa Region Working Paper Series No. 14. World Bank: Washington.

Lewis, J.D., Robinson, S. and Thierfelder, K.,, (1999). 'After the Negotiations: Assessing the Impact of Free Trade Agreements in Southern Africa', Trade and Macroeconomic Division Working Paper No 46. IFPRI: Washington.

Lewis, J.D., Robinson, S. and Thierfelder, K.,, (2001). 'Free Trade Agreements and the SADC Economies', Trade and Macroeconomic Division Working Paper No 80. IFPRI: Washington.

Lipsey, R.G., (1957). 'The Theory of Customs Unions: Trade Diversion and Welfare', Economica, Vol 24, pp 40-6.

Lipsey, R.G., (1960). 'The Theory of Customs Unions: A General Survey’, Economic Journal, Vol 70, pp 496-513.

Lucas, R.E.B., (1985b). 'Migration amongst the Batswana', Economic Journal, Vol 95, pp 358382.

Lucas, R.E.B. and Stark, O., (1985a). 'Motivations to Remit: Evidence from Botswana', Journal of Political Economy, Vol 93, pp 901-918.

Malcolm, G., (1998): Adjusting Tax Rates in the GTAP Data Base, GTAP Technical Paper No 12, Center for Global Trade Analysis, http://www.agecon.purdue.edu/GTAP/techpapr /index.htm

de Melo, J. and Robinson, S., (1989). 'Product Differentiation and the Treatment of Foreign Trade in Computable General Equilibrium Models of Small Economies', Journal of International Economics, Vol 27, pp 47-67. 
Robinson, S. and Thierfelder, K., (1999). 'Trade Liberalization and Regional Integration: The Search for Large Numbers', Trade and Macroeconomic Division Working Paper No 34. IFPRI: Washington.

Stark, O. and Lucas, R.E.B., (1988). 'Migration, Remittances, and the Family', Economic Development and Cultural Change, Vol , pp 465-481.

Vink, N. and Kassier, W.E. (1991). Agricultural policy and the South African State. In: M. de Klerk (ed.). A Harvest of Discontent: The Land Question in South Africa. IDASA, Cape Town. 


\section{Appendix 1: The Data}

\section{Table A1 Aggregation of Commodities}

\begin{tabular}{ll}
\hline \multicolumn{1}{c}{$\begin{array}{c}\text { Model } \\
\text { Commodities }\end{array}$} & \multicolumn{1}{c}{ GTAP 5 Commodities } \\
\hline Crop Agriculture & $\begin{array}{l}\text { Paddy rice; Wheat; Cereal grains nec; Vegetables; fruit; nuts; Oil seeds; Sugar } \\
\text { cane; sugar beet; Plant-based fibers; Crops nec; Fishing; Forestry }\end{array}$ \\
Animal Agriculture Bovine cattle; sheep and goats; horses; Animal products nec; Raw milk; Wool; \\
silk-worm cocoons
\end{tabular}




\section{Table A2 Aggregation of Regions}

\begin{tabular}{ll}
\hline \multicolumn{1}{c}{ Model Region } & \multicolumn{1}{c}{ GTAP 5 Regions } \\
\hline Botswana & Botswana \\
South Africa & SACU less Botswana \\
Rest of SADC & Malawi, Mozambique, Tanzania, Zambia, Zimbabwe, Rest of \\
& southern Africa \\
Rest of Africa & Morocco, Rest of North Africa, Uganda, Rest of sub-Saharan Africa \\
EU & Austria, Denmark, Finland, France, Germany, United Kingdom, \\
& Greece, Ireland, Italy, Netherlands, Portugal, Spain, Sweden, Belgium \\
NAFTA & Canada, United States of America, Mexico \\
MERCUSOR & Argentina, Brazil, Uruguay \\
Rest of Europe & Switzerland, Rest of EFTA, Hungary, Poland, Rest of Central \\
Eest of America & $\begin{array}{l}\text { Curopean Assoc } \\
\text { of Andral America and the Caribbean, Colombia, Peru, Venezuela, Rest }\end{array}$ \\
Rest of the World & Australia, New Zealand, Chile, China, Hong Kong, Japan, Korea, \\
Taiwan, Indonesia, Malaysia, Philippines, Singapore, Thailand, Viet & Nam, Bangladesh, India, Sri Lanka, Rest of South Asia, Former \\
& Soviet Union, Turkey, Rest of Middle East, Rest of World
\end{tabular}




\section{Appendix 2: Model Closure Rules}

The standard GTAP policy closure was adjusted in the following ways:

1) Trade Balance

$$
\begin{aligned}
& \text { swap DTBALR("bwa") }=\text { dpsave("bwa"); } \\
& \text { swap DTBALR("xsc") }=\operatorname{dpsave}(\text { "xsc"); } \\
& \text { swap DTBALR("sad") }=\text { dpsave("sad"); } \\
& \text { swap DTBALR("xaf") }=\text { dpsave ("xaf"); } \\
& \text { swap DTBALR("xwo") }=\text { dpsave("xwo"); }
\end{aligned}
$$

2) Employment

$$
\begin{aligned}
& \text { swap qo("unsklab", "bwa") = pfactreal("unsklab", "bwa"); } \\
& \text { swap qo("unsklab", "xsc") = pfactreal("unsklab", "xsc"); } \\
& \text { swap qo("unsklab", "sad") = pfactreal("unsklab", "sad"); } \\
& \text { swap qo("unsklab", "xaf") = pfactreal("unsklab", "xaf"); } \\
& \text { swap qo("unsklab", "xwo") = pfactreal("unsklab", "xwo"); }
\end{aligned}
$$


a) Exports and the world price of other minerals (diamonds) were fixed 30

swap qxs("mine", "bwa", REG) = tms("mine", "bwa", REG);

swap pfob("mine","bwa", REG) = txs("mine","bwa",REG);

b) Fix quantity and price of Botswana's exports of meats to Europe

swap qxs("food", "bwa", "eur") = tms("food", "bwa", "eur");

swap pfob("ani","bwa","eur") = rxs("ani","bwa","eur");

c) Fix Exports of agricultural crops by Botswana

swap qxw("crops","bwa") = tm("crops","bwa");

29 The method used to fix the quantities and prices of exports was adapted from Adams et al., (forthcoming). The variables rms, rxs and rm operate as rents associated with the closure conditions.

30 Some solution difficulties are encountered when fixing total exports of minerals from Botswana; hence the use of the less general closure condition whereby Botswana's mineral exports by destination are fixed. 